\title{
Desain preparasi gigitiruan cekat mempengaruhi kesehatan jaringan periodontal
}

Edy Machmud

Bagian Prostodonsia

Fakultas Kedokteran Gigi Universitas Hasanuddin

Makassar, Indonesia

\begin{abstract}
The main purpose of treating tooth with fixed restoration (crown or bridge) is to keep healthy the remaining tooth and their surrounding tissue. In order to provide the serviceability fixed partial denture in patient's mouth, so the periodontal tissue should be preserved so natural teeth used as abutment can be also maintained.
\end{abstract}

Key words: fixed partial denture, preparation design, periodontal tissue's health

\begin{abstract}
ABSTRAK
Tujuan utama perawatan gigi dengan suatu restorasi cekat, apakah dengan mahkota atau gigitiruan jembatan, adalah memelihara gigi dan jaringan di sekitarnya yang masih ada agar tetap sehat. Oleh karena itu agar suatu gigitiruan cekat dapat bertahan untuk jangka waktu yang lama di dalam mulut, maka pemeliharaan jaringan periodontal harus tetap dipertahankan agar gigi alami yang digunakan sebagai gigi penyangga juga dapat dipertahankan.
\end{abstract}

Kata kunci: Gigitiruan cekat, desain preparasi dan kesehatan jaringan periodontal.

Koresponden: Edy Machmud, Bagian Prostodonsia, Fakultas Kedokteran Gigi Universitas Hasanuddin, J1. Kandea No.5 Makassar, Indonesia.

\section{PENDAHULUAN}

Preparasi tepi servikal merupakan tahap preparasi yang paling penting yang menentukan keberhasilan perawatan gigitiruan cekat (GTC), karena pada tahap preparasi ini ditempatkan pada daerah pertemuan antara jaringan gigi penyangga dengan tepi restorasi. Letak akhiran servikal di sekitar leher gigi yang berbatasan dengan gingiva, sehingga plak mudah terakumulasi dan hal ini merupakan tahap awal terjadinya penyakit periodontal. Penyakit periodontal merupakan penyakit yang sering dijumpai di dalam mulut selain karies. Di Amerika Serikat, 60\%-70\% gigi yang hilang sesudah usia 40 tahun disebabkan oleh penyakit periodontal. Di Kanada, 45\% penduduk yang berusia 35-44 tahun mengalami kehilangan gigi karena penyakit periodontal. Sedangkan di Indonesia berdasarkan laporan Departemen Kesehatan, disebutkan bahwa prevalensi karies dan penyakit periodontal masih tinggi, yaitu sebesar $74,41 \%{ }^{1}$

Preparasi tepi servikal dapat diletakkan di supragingiva, subgingiva atau setinggi puncak gingiva. Namun beberapa ahli di bidang prostodonsia dan periodonsia menganjurkan penempatan tepi preparasi di supragingiva, karena batas preparasinya cukup jelas terlihat, lebih mudah dibersihkan dan dikontrol serta tidak mengiritasi gingiva. Akan tetapi hal yang perlu dipertimbangkan pada desain preparasi supragingiva ini adalah faktor estetik pada gigi anterior dan gigi premolar terutama pada rahang 
atas. Desain preparasi subgingiva umum dilakukan untuk restorasi yang membutuhkan faktor estetik, tetapi desain ini menurut para ahli akan menyebabkan inflamasi pada jaringan gingiva. Oleh karena itu dewasa ini desain preparasi servikal diletakkan setinggi puncak gingiva untuk mengakomodasi restorasi yang membutuhkan faktor estetik dan sekaligus menjamin kesehatan jaringan gingiva.

Menurut bentuknya, desain akhiran tepi preparasi dibedakan atas preparasi knife edge/ feather edge atau shoulderless (tanpa bahu), preparasi shoulder (dengan bahu), preparasi bevel shoulder (bahu dengan kemiringan) dan akhiran preparasi chamfer. Desain akhiran preparasi tanpa bahu kekurangannya adalah pengambilan jaringan yang minimal sehingga memungkinkan terjadinya over contour yang menyebabkan akumulasi plak mudah terjadi di tepi servikal restorasi yang berbatasan dengan gingiva. Desain akhiran preparasi chamfer mempunyai batas pengambilan jaringan yang lebih sedikit daripada preparasi bahu dan sedikit lebih banyak daripada preparasi tanpa bahu, sehingga tidak menyebabkan restorasi yang overcontour dan adaptasi tepi sevikal yang memadai. Dengan desain akhiran preparasi servikal dengan bahu memungkinkan operator untuk menentukan seberapa besar pengambilan jaringan gigi (lebar bahu). Lebar bahu ini diperlukan untuk menahan beban insisal atau oklusal. Desain preparasi ini merupakan preparasi yang tepat untuk restorasi mahkota logam porselen, restorasi mahkota tunggal, restorasi jembatan metal porselen dan restorasi jembatan metal akrilik. Namun penggunaan logam sebagai coping GTC mempunyai kerugian karena sifat logam yang mudah menyusut dan penyusutan coping logam lebih besar lagi setelah pembakaran porselen sebagai bahan pelapis estetik, sehingga menyebabkan kurangnya adaptasi pada bagian tepi servikal restorasi. ${ }^{2}$ Desain akhiran preparasi servikal bahu dengan kemiringan dibuat untuk mencegah adaptasi servikal yang kurang baik, tetapi penempatan bevel yang dibuat $0,5-1,0 \mathrm{~mm}$ di bagian subgingiva dapat menyebabkan inflamasi pada jaringan gingiva. ${ }^{2}$

Tujuan penulisan makalah ini adalah untuk membahas pengaruh desain preparasi gigitiruan cekat terhadap kesehatan jaringan periodontal.

\section{TINJAUAN PUSTAKA}

Gigitiruan cekat adalah suatu gigitiruan yang menggantikan satu atau lebih gigi alami yang hilang, yang dilekatkan secara permanen dengan menggunakan semen ke gigi penyangga yang telah dipreparasi. ${ }^{4}$

\section{Preparasi gigi $^{5}$}

Preparasi gigi merupakan salah satu tahap yang penting dalam pembuatan mahkota logam porselen sehingga harus dilakukan secara hatihati terutama pada preparasi subgingiva, agar tidak melukai jaringan gingiva terutama yang tipis dan halus. Bila perlekatan gingiva mengalami luka yang terjadi selama preparasi, dapat menyebabkan resesi. Preparasi subgingiva harus berakhir $0,5 \mathrm{~mm}$ lebih pendek dari perlekatan epitel.

Bur yang digunakan dapat melukai dan merusak jaringan gingiva, sehingga kontur jaringan lunak secara estetis menjadi buruk. Oleh karena itu diperlukan pengurangan jaringan gigi yang memadai untuk memberi ruangan yang cukup, baik untuk penampilan estetik maupun fungsi yang normal.

\section{Desain preparasi tepi servikal}

Penyelesaian akhir tepi restorasi sangat diperlukan agar didapatkan suatu bentuk 
permukaan yang dapat meminimalkan retensi plak dan memaksimalkan adaptasi GTC itu sendiri pada gigi. Tepi restorasi dapat diletakkan di atas jaringan gingiva (supragingiva), setinggi puncak gingiva (equigingiva) dan di bawah gingiva (subgingiva). Kenyataannya bahwa jaringan periodontal di sekeliling tepi mahkota berakhiran subgingiva lebih memperlihatkan peradangan dibandingkan mahkota dengan akhiran supragingiva. Inflamasi gingiva di sekeliling GTC terjadi karena peningkatan retensi plak. Oleh karena itu tepi restorasi lebih baik diletakkan pada supragingiva. Tetapi kenyataannya hal ini tidak mungkin selalu dilakukan, karena ada sejumlah faktor lain yang juga berpengaruh dalam penentuan keputusan, yaitu pertimbangan estetik, mahkota klinis yang pendek, karies subgingiva, dan kepekaan terhadap karies akar. ${ }^{1}$

Berdasarkan lokasinya dikenal tiga jenis akhiran preparasi, yaitu akhiran preparasi supragingiva, akhiran preparasi subgingiva, dan akhiran preparasi setinggi gingiva. Sedangkan menurut bentuknya dikenal empat macam akhiran preparasi, yaitu knife-edge/feather edge, preparasi shoulder, preparasi bevel shoulder, dan akhiran preparasi chamfer.

\section{Penempatan akhiran preparasi supragingiva}

Kontak restorasi mahkota logam porselen dengan daerah gingiva dapat dihindari dengan menempatkan tepi restorasi pada supragingiva. Tepi akhir supragingiva meningkatkan potensi untuk memperoleh kesehatan gingiva yang optimal di sekitar gigi yang telah dipreparasi. Selain itu tepi akhir supragingiva juga dapat memenuhi tuntutan estetik Pada $33 \%$ pasien, aspek labial dari gigi anterior yang dirawat mahkota logam porselen dengan akhiran preparasi supragingiva tidak memberikan keluhan masalah estetik. Menurut para ahli bidang periodonsia, akhiran preparasi tepi servikal sebaiknya ditempatkan di supragingiva untuk menjamin kesehatan jaringan periodontal. ${ }^{6}$

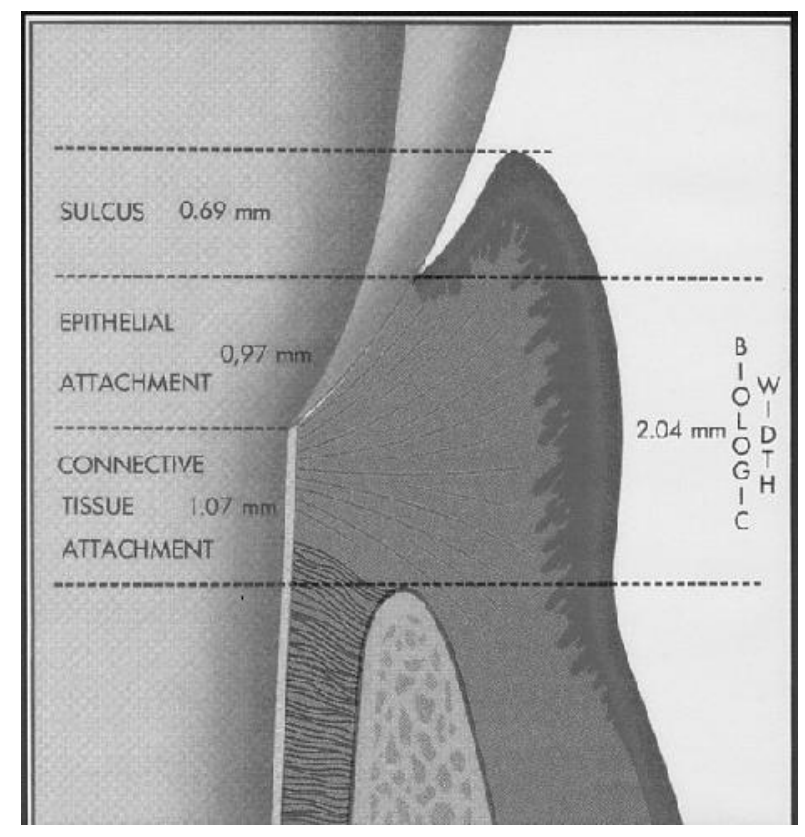

Gambar 1.Lebar biologis dan epithelial attachment (Sumber: Treatment of a gummy smile. Available from: http://www.bluegrass.kctcs.edu/home page.htm. Accessed: February 12, 2006). ${ }^{12}$

\section{Penempatan akhiran preparasi subgingiva}

Berdasarkan berbagai penelitian, disimpulkan bahwa tepi subgingiva sebaiknya dihindari, kecuali pada beberapa keadaan seperti kebutuhan estetik, karies pada subgingiva, restorasi pada servikal, menambah panjang mahkota klinis, dan untuk menghasilkan kontur mahkota yang lebih baik $^{6,7}$ Penempatan akhiran preparasi subgingiva memungkinkan kesehatan jaringan gingiva dan jaringan periodontal dapat dipertahankan, tetapi membutuhkan keterampilan dalam melakukan tindakan preparasi prosedur klinis yang hati-hati agar tidak menciderai jaringan gingiva. ${ }^{7,8}$

Jika akhiran preparasi tepi servikal harus ditempatkan di subgingiva, maka harus 
diperhatikan konsep lebar biologis, yaitu jarak dari perlekatan epitel sampai ke puncak tulang alveolar, yaitu antara 2,04-3,0 mm (gambar 1). Berdasarkan konsep ini maka akhiran preparasi tepi servikal sebaiknya ditempatkan lebih dari 2,0 $\mathrm{mm}$ di atas puncak tulang alveolar. ${ }^{9}$

\section{Penempatan akhiran preparasi setinggi puncak gingiva}

Penempatan akhiran preparasi setinggi puncak gingiva lebih baik hasilnya jika dibandingkan dengan akhiran preparasi subgingiva, karena pada akhiran preparasi setinggi puncak gingiva iritasi terhadap jaringan periodontal dijumpai lebih kecil ${ }^{1}$

\section{Knife- edge/feather edge atau shoulderless}

Bentuk preparasi ini dapat digunakan untuk restorasi yang terbuat dari logam. Keuntungan dari bentuk akhirann preparasi ini adalah pengambilan jaringan yang lebih sedikit, namun preparasi tidak dapat dievaluasi secara tepat pengurangan di bagian tepi servikal sehingga dapat mengakibatkan akhiran tepi servikal terlalu dalam di sulkus gingival dan mengiritasi jaringan periodontal. ${ }^{1,6}$

Kekurangan dari akhiran tepi servikal knife-edge ini adalah batasnya sulit dilihat secara jelas pada gigi yang dipreparasi maupun pada model. Bentuk akhiran ini memerlukan pengamatan secara lebih teliti oleh laboran terutama pada saat membuat pola malamnya. Bentuk knife-edge merupakan akhiran tepi servikal yang digunakan pula pada restorasi yang terbuat dari bahan emas karena preparasinya dapat dibuat secara lebih mudah dan pengambilan jaringan gigi tidak terlalu banyak, sehingga tidak membahayakan jaringan pulpa gigi. ${ }^{1,6}$

\section{Preparasi shoulder (bentuk bahu penuh)}

Preparasi shoulder ini adalah preparasi yang mempunyai bahu mengelilingi seluruh servikal sehingga disebut full shoulder atau partial shoulder jika hanya bagian labial/bukal. Preparasi ini lebih menjamin adanya ruangan yang cukup di daerah servikal terutama untuk kelompok restorasi metal porselen atau metal akrilik. Teknik preparasi ini lebih sulit dan tidak mungkin dikerjakan pada gigi yang mempunyai ruang pulpa yang besar. Bur yang digunakan dalam pembuatan akhiran tepi servikal ini adalah bur bentuk fisur runcing yang ujungnya rata. Bur ini digunakan apabila diperlukan ruangan untuk penempatan restorasi yang terbuat dari porselen. ${ }^{1,6}$

\section{Preparasi bevel shoulder (bentuk setengah bahu)}

Bentuk akhiran tepi servikal ini merupakan kombinasi dari bentuk bahu penuh yang disertai dengan bevel. Preparasi bevel shoulder ternyata dapat menghasilkan kontur yang baik untuk penempatan tepi restorasi karena jika bahu ditempatkan pada lokasi yang tepat maka tepi bevel dapat berada dalam sulkus gingival tanpa mengganggu dasar sulkus gingiva. Preparasi ini memenuhi dua syarat penting pada pada daerah servikal yaitu, memberikan ruangan yang cukup untuk bahan restorasi yang diperoleh dari bahu dan memungkinkan adaptasi tepi yang adekuat dari bevel. Untuk membuat bahu dan bevel di subgingiva, bahu perlu dipreparasi setinggi tepi gusi yang sehat dan kemudian ditambahkan bevel 0,3-0,5 $\mathrm{mm}$. Cara preparasi ini memungkinkan kontrol penempatan tepi restorasi dengan baik. Bentuk bevel shoulder ini digunakan sebagai akhiran tepi servikal pada restorasi metal porselen, namun porselen tidak ditempatkan pada bagian bevelnya. Bagian bevel biasanya 
ditempati oleh metal collar atau restorasi yang bagian leher/tepi servikalnya terbuat dari logam. ${ }^{1,6}$

\section{Akhiran preparasi bentuk chamfer}

Beberapa peneliti menganggap sebuah akhiran servikal yang bersudut tumpul atau bentuk dengan potongan melintang yang melengkung disebut dengan chamfer. Bell dkk yang dikutip oleh Reitemeier menyatakan bahwa preparasi dilakukan dengan pengurangan setebal $1,5 \mathrm{~mm}$, sudut garis internal yang membulat dan sudut cavosurface sebesar $135^{\circ}$. Desain preparasi tepi ini sangat menguntungkan jika dipakai untuk mahkota logam porselen, karena tepi logamnya dapat dibuat relatif tipis. Bentuk chamfer seringkali digunakan sebagai akhiran tepi servikal dari restorasi yang terbuat dari logam, namun bukan berarti bahwa bentuk chamfer ini lebih istimewa jika dibandingkan dengan bentuk akhiran preparasi servikal lainnya. ${ }^{6}$

\section{PEMBAHASAN}

Akhiran preparasi yang dibuat dan ditempatkan di subgingiva akan menyebabkan terjadinya peradangan pada gingival. ${ }^{10}$ Peradangan ini diawali dengan pembentukan deposit plak pada daerah perbatasan antara restorasi dan daerah preparasi gigi di bagian servikal. Pembentukan plak pada daerah tersebut sulit dibersihkan. Menurut Crip ${ }^{11}$ yang mengutip Waerhaug, dinyatakan bahwa plak tersebut akan berkembang dan menginvasi jaringan periodontal sampai ke daerah apikal gigi penyangga.

Desain tepi servikal yang kurang baik akan menyebabkan adaptasi tepi restorasi yang kurang baik pula. ${ }^{7}$ Demikian pula halnya dengan restorasi yang over hanging akan menyebabkan retensi plak yang merupakan tanda awal dari penyakit periodontal. ${ }^{8}$ Overkontur mahkota dan daerah kontak yang tidak rapat juga dapat menyebabkan penumpukan sisa makanan. ${ }^{10}$

\section{SIMPULAN}

Dari pembahasan di atas, dapat disimpulkan bahwa desain preparasi servikal sebaiknya ditempatkan di daerah supragingiva untuk mencegah peradangan pada jaringan pendukung gigi. Namun apabila desain preparasi tepi servikal harus ditempatkan secara subgingiva oleh karena beberapa alasan, maka konsep lebar biologis harus tetap diperhatikan.

\section{DAFTAR PUSTAKA}

1. Elias S. Beberapa pertimbangan pada preparasi akhiran servikal dalam menunjang keberhasilan restorasi gigitiruan cekat. Majalah Ilmiah Kedokteran Gigi Fakultas Kedokteran Gigi Universitas Trisakti. Edisi khusus FORIL V; 1996. p.785, 790-2.

2. Gemalmaz D, Sule E. Clinical evaluation of all ceramic crowns. J Prosthet Dent 2002; 87: 189-96.

3. Fayyad MA. A visual method of determining placement of crown: Part I. Marginal placement of anterior crowns. Quintessence Int 1995; 26(5): 325-8.

4. Allan DN, Foreman PC. Petunjuk bergambar mahkota dan jembatan. Alih bahasa: Djaya A. Editor: Juwono L. Jakarta: Hipokrates; 1994. p.43.

5. Goodacre CJ, Wayne CV, Steven AA. Tooth preparation for complete crowns: An art form based on scientific. J Prosthet Dent 2001; 85: 369-70.

6. Reitemeier $\mathrm{D}$, Hansel $\mathrm{K}$, Walter $\mathrm{MH}$, Kastner C, Toutenburg H. Effect of posterior crown margin placement on gingival health. J Prosthet Dent 2002; 75 : 217-27.

7. Rosenstiel SF, Land MF, Crispin BJ. Dental luting agents: $\mathrm{A}$ review at the current literature. J Prosthet Dent 1998; 80: 280301.

8. Lesmana RA. Faktor-faktor periodontal yang harus dipertimbangkan pada 
perawatan dengan gigitiruan cekat. Jurnal Kedokteran Gigi Fakultas Kedokteran Gigi Universitas Indonesia 1999; 39: 40-2.

9. Srdjak KJ, Plancak D, Maricevic T, Dragoo MR, Bosnjak A. Periodontal and prosthetic aspect of biological width. Part I: Violation of biologic width. Acta Stomatol Croat 2000; 34: 195-7.
10. Eccles JD, Green RM. The conservation of teeth. $2^{\text {nd }}$ ed. London: Blackwell Scientific Pub.; 1983. p. 227-30.

11. Cripp S. Periodontal disease: Recognition interceptional and prevention. Chicago: Quintessence Pub. Co.; 1984. p.152.

12. Treatment of a gummy smile. Available from:http://www.bluegrass.kctcs.edu/home page.htm. Accessed: February 12, 2006. 